\title{
Single Dose Vial
}

National Cancer Institute

\section{Source}

National Cancer Institute. Single Dose Vial. NCI Thesaurus. Code C43215.

A vial containing a single unit of a parenteral drug product. 